\title{
The Characteristics of Iron Ore Slimes and Their Influence on The Flotation Process
}

\author{
Neymayer Pereira Lima ${ }^{1}$, Klaydison Silva ${ }^{1}$, Thiago Souza ${ }^{2}$ and Lev Filippov ${ }^{3, *(D)}$ \\ 1 Av. Dr. Marco Paulo Simon Jardim, 3580 Bairro Piemonte, Nova Lima CEP 34.006-200, MG, Brazil; \\ neymayer.lima@vale.com (N.P.L.); klaydison.silva@vale.com (K.S.) \\ 2 Vale Institute of Technology, Avenida Juscelino Kubitschek, Bauxita Ouro Preto 31, MG, Brazil; \\ thiago.souza@itv.org \\ 3 Université de Lorraine, CNRS, GeoRessources, F54000 Nancy, France \\ * Correspondence: lev.filippov@univ-lorraine.fr
}

Received: 21 May 2020; Accepted: 22 July 2020; Published: 30 July 2020

\begin{abstract}
The flotation has been successfully applied to process the iron ore for the particle size (Ps) from $10 \mu \mathrm{m}$ up to $150 \mu \mathrm{m}$. The presence of the slimes (Ps $<10 \mu \mathrm{m}$ ) is harmful on the reverse flotation of quartz, so they are usually prior removed by hydrocyclones. The main effects of the presence of slimes on the flotation are related to the increase on reagents consumption, the froth stability, and decrease on the selectivity. The lower floatability of coarse quartz particles $(+74 \mu \mathrm{m})$ combined with the presence of slimes, even in small quantities, drastically affect the flotation response. This paper shows a study of characterization of a typical iron ore slime, aiming to create a better understanding of its role on the concentration by flotation. The main characteristics of typical slimes from the Iron Ore Quadrangle in Brazil are the presence of almost 70\% of hematite, 25\% of quartz, and $5 \%$ of kaolinite, as the main silicates gangue minerals. Furthermore, the particle size distribution revealed that $80 \%$ of the hematite and the kaolinite are below $20 \mu \mathrm{m}$. The affinity between the ultrafine kaolinite of the slimes with the corn starch is harmful to the reverse flotation of quartz, as the starch has an important depressing action over the hematite. The presence of $20 \%$ of hematite $-20 \mu \mathrm{m}$ decreased the recovery to the froth of quartz $+74 \mu \mathrm{m}$ from $97 \%$ to $62 \%$, where the slimes coating seems to be the main responsible.
\end{abstract}

Keywords: iron ore; slimes; kaolinite; flotation

\section{Introduction}

The flotation of iron ores is performed in circuits that consist of mechanical cells, columns, or a combination of both types of machine. The feed consists of particles in the size range between $10 \mu \mathrm{m}$ and $150 \mu \mathrm{m}$ [1]. The slimes (fraction $<10 \mu \mathrm{m}$ ) are removed in hydrocyclones and the top size is limited to $5 \%$ to $10 \%>150 \mu \mathrm{m}$. This wide range of particles size impairs process selectivity due to the possible differences in behavior concerning properties, such as hydrophobicity, specific surface area, weight, etc. [2]. Understanding the characteristics and behavior of the slimes is of fundamental importance on the iron ore flotation industry, as the operational conditions can be better adjusted to maximize Fe recovery and product quality [3]

The harmful effects of iron slimes on the reverse flotation of quartz have been known since the beginning of its operation [1]. The main effects refer to the increase of reagents consumption, the lower selectivity and the froth stability [4]. The removal of iron ore slimes using hydrocyclones was introduced with the USBM process [5]. Investigations that were carried out by Lima and coworkers for different iron ores from the Iron Quadrangle in the Southeast of Brazil indicated that the by-pass levels on the desliming hydrocyclones lower than $4 \%$ did not affect the flotation recoveries or the quality of 
the concentrates [6]. The results of this study indicated that the specific surface area with different by pass levels can explain the flotation response on the presence of slimes.

Filippov and coworkers reported the effect of desliming in wet magnetic separation, applied to tailings from magnetite ores processing, at the Mikhailovsky plant in Russia [7]. The authors demonstrated that desliming at $10 \mu \mathrm{m}$ reveals higher mass pull and lower iron grades when desliming at $20 \mu \mathrm{m}$. Despite $10 \%$ higher mass pull at $10 \mu \mathrm{m}$, cutting at $20 \mu \mathrm{m}$ have shown a dramatic increase on the flotation selectivity. Table 1 shows the effect of the desliming size on the flotation response.

Table 1. Influence of desliming on the reverse cationic flotation of hematite containing tailings of magnetic separation from magnetite ore at the Mikhailovsky plant, Russia [6].

\begin{tabular}{cccccc}
\hline Desliming & Products & wt $\%$ & \multicolumn{2}{c}{ Grade\% } & Fe Recovery\% \\
\hline \multirow{3}{*}{$<10 \mu \mathrm{m}$} & Concentrate & 58.5 & 39.2 & 35.8 & 72.8 \\
& Tailings & 41.5 & 20.6 & 62.3 & 27.2 \\
& Magnetic product & 100 & 31.5 & 46.8 & 100 \\
$<20 \mu \mathrm{m}$ & Concentrate & 49.8 & 54.9 & 10.8 & 73.5 \\
& Tailings & 50.2 & 19.6 & 66.5 & 26.5 \\
& Magnetic product & 100 & 37.2 & 38.8 & 100 \\
\hline
\end{tabular}

Studies that were conducted by Thella and coworkers with the iron slimes stored in slimes pond showed the possibility to obtain concentrates with $64.46 \% \mathrm{Fe}, 2.66 \% \mathrm{Al}_{2} \mathrm{O}_{3}$, and $2.05 \% \mathrm{SiO}_{2}$ with the combination of two stages of hydrocyclones of $50 \mathrm{~mm}$ of diameter with vortex finders of $14.3 \mathrm{~mm}$ and $11 \mathrm{~mm}$ of diameters to remove the particles with high content of $\mathrm{Al}_{2} \mathrm{O}_{3}$ and enhance the flotation selectivity while using amines and starch [8]. Ma and coworkers observed that starch adsorption in kaolinite is $\mathrm{pH}$ dependent, with starch adsorption decreasing with increasing $\mathrm{pH}$ from 7 to 10.5 [9] at pH 10.5, increasing ionic strength significantly enhances the adsorption density of starch on kaolinite.

Weissenborn and coworkers studied the optimization of selective flocculation of ultra-fine iron ore aiming the increase of Fe content in tailings samples where kaolinite was the main gangue mineral [10]. The results indicated the possibility to increase the Fe content from $46.6 \%$ to $57 \%$. Wheat starch was the most appropriate selective flocculant. The recovery of all minerals was very sensitive to changes in flocculation conditions, and careful control of the many process variables was required in order to achieve optimum recovery.

$\mathrm{Xu}$ and coworkers evaluated the floatability of kaolinite in different sizes and with different chain length collectors [11]. The anomalous flotation behaviour of kaolinite have been explained based on crystal structure considerations. The results showed that fine kaolinite particles have more edges to adsorb fewer cationic collectors than that of coarse kaolinite particles, which is responsible for the poorer floatability of fine kaolinite.

Dey and coworkers evaluated the concentration of Indian iron ore slime using column flotation [12]. A sample with $16 \%$ passing in $25 \mu \mathrm{m}$ size fraction containing $58.7 \% \mathrm{Fe}, 5.2 \% \mathrm{SiO}_{2}$, and $4.9 \% \mathrm{Al}_{2} \mathrm{O}_{3}$ was used during the investigations in a column of $7.5 \mathrm{~cm}$ diameter and $3 \mathrm{~m}$ height. The tests of direct flotation were carried out using a pulp with $10 \%$ of solids $(w / w)$, sodium silicate as depressant, MIBC as frother and sodium oleate as collector. A concentrate with $62 \%$ Fe and $59 \%$ yield was produced using $2.5 \mathrm{~kg} / \mathrm{t}$ of collector at $0.5 \mathrm{~cm} / \mathrm{s}$ of superficial air velocity.

Slimes have higher surface area, which increases the reagent consumption and they can increase flotation residence time resulting in high froth volumes ([13]. Lima and coworkers evaluated the effect of the by-pass on the reverse flotation of quartz for samples with different mineralogical compositions [6]. The specular hematite sample was affected by the increase of by-pass level from $4 \%$ to $6 \%$, on the contrary of the goethite/porous hematite sample, which was not affected when the by-pass level increased from $2 \%$ to $8 \%$. This study showed the higher specific surface area of the specular hematite sample with $6 \%$ of by-pass can be the cause of the higher grade of $\mathrm{SiO}_{2}$ on the concentrate, as reported in Table 2. 
Table 2. Effect of the specific surface area on the flotation behavior of iron ores presenting different mineralogical compositions [6].

\begin{tabular}{ccccc}
\hline $\begin{array}{c}\text { Mineralogical } \\
\text { Composition }\end{array}$ & By-Pass (\%) & $\begin{array}{c}\text { Specific Surface } \\
\text { Area }\left(\mathbf{c m}^{2} / \mathbf{g}\right)\end{array}$ & $\begin{array}{c}\text { Fe Distribution } \\
\text { in Concentrate }\end{array}$ & $\begin{array}{c}\text { SiO }_{2} \text { in } \\
\text { Concentrate }\end{array}$ \\
\hline \multirow{2}{*}{ Specular hematite } & 4 & 1000 & 69.7 & 1.2 \\
& 6 & 3000 & 67 & 2.7 \\
\hline \multirow{3}{*}{ Goethite/porous hematite } & 2 & 1295 & 92.9 & 1 \\
& 8 & 1556 & 92.5 & 1.1 \\
& 8 & 1887 & 90.7 & 1.1 \\
\hline
\end{tabular}

Bandini and coworkers analyzed the effect of colloidal iron ore slime on the flotation of galena and quartz particles by coatings [14]. These authors investigated the formation of iron ore slime coatings and methods for their removal, using quartz as a model for deslimed galena, since it shows similar surface electrical properties and slime particle adsorption characteristics. The use of $\mathrm{pH}$ control alone was ineffective in removing iron oxide slime coatings from galena or quartz. By increasing the $\mathrm{pH}$ to 10 , both iron oxide and galena/quartz particles become negatively charged; however, there is still an energy barrier to overcome for slime detachment. Combining $\mathrm{pH}$ control with high shear mixing or sonication removed rapid and completely the iron ore slime coatings.

Rulyov and coworkers evaluated the microfotation of particles below $1 \mu \mathrm{m}$. The use of $40 \mu \mathrm{m}$ bubbles and the coagulation or flocculation of particles to reach $7 \mu \mathrm{m}$ were necessary to increase their recovery [15].

The presence of slimes in the beneficiation plants of the Iron Ore Quadrangle in Brazil have increased even more, reaching almost 40 million of tons per annum. Understanding the harmful effect of these slimes on the iron ore flotation is a challenging and it can be useful to develop alternatives to increase the Fe recovery on the beneficiation plants.

\section{Materials and Methods}

\subsection{Samples}

This study was carried out using eight samples, as described in Table 3.

Table 3. General characteristics of the samples.

\begin{tabular}{|c|c|c|c|c|}
\hline Sample & Sample Name & Mass of Solids (kg) & Source & Description \\
\hline 1 & Iron ore slime & 150 & Industrial slime thickener & $\begin{array}{l}\text { Iron ore slime collected on the } \\
\text { underflow's thickener }\end{array}$ \\
\hline $1 \mathrm{~A}$ & Hematite & 20 & Industrial slime thickener & $\begin{array}{c}\text { Concentrate obtained after several } \\
\text { stages of bench scale magnetic } \\
\text { separation of sample } 1\end{array}$ \\
\hline $1 \mathrm{~B}$ & Silicates & 20 & Industrial slime thickener & $\begin{array}{l}\text { Tailing obtained after several } \\
\text { stages of bench scale magnetic } \\
\text { separation of sample } 1\end{array}$ \\
\hline $2 \mathrm{~A}$ & $\begin{array}{l}\text { Iron ore desliming feed } \\
\text { with } 21 \% \mathrm{SiO}_{2}+74 \mu \mathrm{m}\end{array}$ & 150 & $\begin{array}{c}\text { Industrial desliming } \\
\text { cyclones }\left(20^{\circ} \text { of diameter }\right)\end{array}$ & $\begin{array}{l}\text { Iron ore desliming feed collected } \\
\text { on } 20^{\circ} \text { cyclones feed }\end{array}$ \\
\hline $2 \mathrm{~B}$ & $\begin{array}{l}\text { Iron ore desliming feed } \\
\text { with } 21 \% \mathrm{SiO}_{2}+74 \mu \mathrm{m}\end{array}$ & 150 & $\begin{array}{c}\text { Industrial desliming } \\
\text { cyclones }\left(20^{\circ} \text { of diameter }\right)\end{array}$ & $\begin{array}{l}\text { Iron ore desliming feed collected } \\
\text { on } 20^{\circ} \text { cyclones feed }\end{array}$ \\
\hline $2 \mathrm{C}$ & $\begin{array}{l}\text { Iron ore desliming feed } \\
\text { with } 21 \% \mathrm{SiO}_{2}+74 \mu \mathrm{m}\end{array}$ & 150 & $\begin{array}{l}\text { Industrial desliming } \\
\text { cyclones }\left(20^{\circ} \text { of diameter }\right)\end{array}$ & $\begin{array}{l}\text { Iron ore desliming feed collected } \\
\text { on } 20^{\circ} \text { cyclones feed }\end{array}$ \\
\hline 3 & Pure quartz & 10 & Minas Gerais, Brazil & $\begin{array}{c}\text { Pure samples of quartz crushed by } \\
\text { jaw and gyratory crushers and } \\
\text { milled to }>110 \mu \mathrm{m}\end{array}$ \\
\hline 4 & Pure hematite & 10 & Minas Gerais, Brazil & $\begin{array}{c}\text { Pure samples of hematite crushed } \\
\text { by jaw and gyratory crushers and } \\
\text { milled to }>186 \mu \mathrm{m}\end{array}$ \\
\hline
\end{tabular}


Sample 1 was collected on the underflow of the thickener of an industrial beneficiation plant in the Iron Quadrangle, before the disposal on tailings dam. Samples 1A and 1B were obtained from sample 1 after three cleaning and three of scavenging stages, aiming to obtain the highest grades of Fe on the concentrate and silicates on the tailing.

Sample 1 was also submitted to settling in a $2000 \mathrm{~mL}$ beaker, aiming to obtain settling products (underflow) with different percentage of gangue minerals, especially aluminosilicates. The sedimentation tests were carried out on the following conditions. The percentage of solids in the feed was $5 \%$. The pulp $\mathrm{pH}$ was 10.5 aiming the dispersion of the pulp. Settling time after dispersion of the pulp was put at rest for $5 \mathrm{~min}$. Cut-off-size during desliming was at $10 \mu \mathrm{m}$ and the corn starch dosages were $0,100,250$, and $500 \mathrm{~g} / \mathrm{t}$. The obtained underflow samples were used for bench scale flotation tests with $100 \mathrm{~g} / \mathrm{t}$ of collector (Ether amine Flotigam 7100 by Clariant, Muttenz, Switzerland), $500 \mathrm{~g} / \mathrm{t}$ of corn starch as depressant at $\mathrm{pH} 10$ and using Denver $1200 \mathrm{~mL}$ bench scale cell.

Samples 2A, 2B, and 2C were collected on the desliming hydrociclones feed of the same industrial beneficiation plant. The samples were collected in different days, when the $\%$ of $\mathrm{SiO}_{2}$ on the $+74 \mu \mathrm{m}$ were $20 \%, 23 \%$, and $31 \%$, respectively. Each of these three samples were deslimed at bench scale to obtain $1.5 \%, 3.5 \%, 5.5 \%$, and $10.0 \%$ of slimes in the flotation feed composition. These tests were done aiming at evaluate the combined effect of slimes and the distribution of $\mathrm{SiO}_{2}$ on the $+74 \mu \mathrm{m}$ in the flotation feed. The flotation tests combining the $\%$ of $\mathrm{SiO}_{2}$ on the $+74 \mu \mathrm{m}$ fraction and the $\%$ of slimes were done with $100 \mathrm{~g} / \mathrm{t}$ of collector (Ether amine Flotigam 7100 by Clariant), $500 \mathrm{~g} / \mathrm{t}$ of corn starch, and $\mathrm{pH} 10.5$ in a $1200 \mathrm{~mL}$ Denver cell.

Samples 3 and 4 are pure quartz and hematite minerals from Minas Gerais, Brazil. They were crushed using jaw and gyratory crusher and milled using ceramic ball mill to reach the size fraction approximately below $200 \mu \mathrm{m}$. The quartz sample was screened to obtain $+74 \mu \mathrm{m}$ for the flotation tests. The hematite sample was classified using a cyclosizer in $+20 \mu \mathrm{m}$ and $-20 \mu \mathrm{m}$ fractions. The flotability of quartz in the presence of hematite $(+20 \mu \mathrm{m}$ and $-20 \mu \mathrm{m})$ was evaluated using $100 \mathrm{~g} / \mathrm{t}$ of collector (Ether amine Flotigam 7100 by Clariant), $500 \mathrm{~g} / \mathrm{t}$ of corn starch as depressant at $\mathrm{pH} 10$, and using MineMet $300 \mathrm{~mL}$ bench scale. The proportion of coarse quartz and fine hematite was almost the same in typical desliming feed, as $80 \%$ and $20 \%$, respectively.

\subsection{Characterizations}

Chemical assays were done by X-ray fluorescence (XRF) by Thermo Fisher Scientific Niton XL3t XRF Analyzer (Thermo Fisher Scientific, Waltham, MA, USA), to determine $\mathrm{Fe}, \mathrm{SiO}_{2}, \mathrm{Al}_{2} \mathrm{O}_{3}, \mathrm{P}, \mathrm{Mn}, \mathrm{CaO}, \mathrm{MgO}$, and LOI. The error of chemical analysis was evaluated to $2 \%$.

Size distribution was obtained by laser sizer instrument (Malvern ${ }^{\circledR}$ Mastersizer 2000, Malvern, Malvern, UK).

The mineralogical composition of sample 1 was determined using an X-ray diffraction technique and the automated scanning electron microscope (QEMSCAN ${ }^{\circledR}$ system) with a tungsten source from the FEI company (Hillsboro, OR, USA). The iDiscover software (everly Hills, CA, USA) was used for the measurements and the data processing. The PMA (Particle Mineral Analysis) analysis model was used. The QEMSCAN ${ }^{\circledR}$ was operated using a voltage acceleration of $15 \mathrm{kV}$ and a current of approximately $5 \mathrm{nA}$. For the X-ray diffraction, the samples were pressed and analyzed in a PANalytical X-ray diffractometer (Empyrean model) while using a Co tube. The crystalline phases were identified and interpreted by the High Score Plus software (Malvern Panalytical, Worchestershire, UK) and the mineralogical composition was quantified by the Rietveld method.

\section{Results and Discussion}

The chemical analyses and size distribution of the iron ore slime, sample 1 are shown in Table 4 and Figure 1, respectively. 
Table 4. Chemical analyses of the iron ore slime (sample 1).

\begin{tabular}{|c|c|c|c|c|c|}
\hline $\mathrm{Fe}(\%)$ & $\mathrm{SiO}_{2}(\%)$ & $\mathrm{Al}_{2} \mathrm{O}_{3}(\%)$ & $P(\%)$ & Mn (\%) & LOI (\%) * \\
\hline 45.17 & 28.64 & 3.06 & 0.085 & 0.91 & 3.07 \\
\hline
\end{tabular}

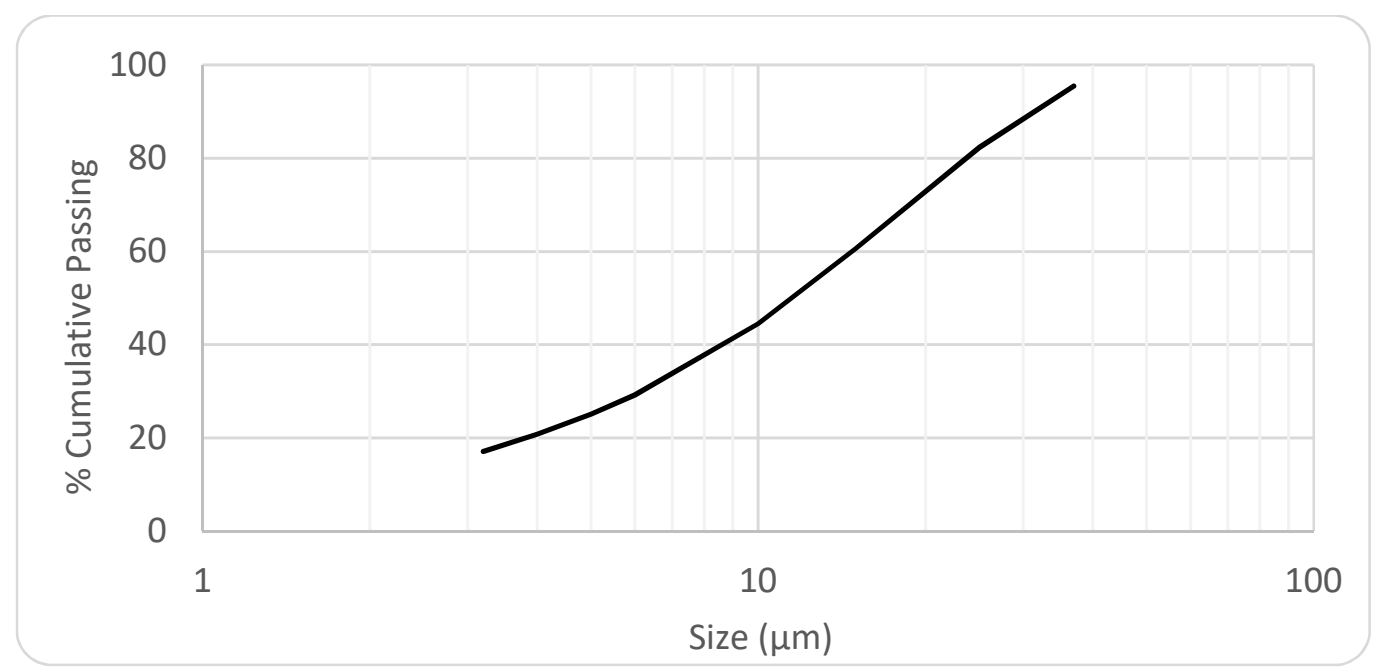

Figure 1. Particle size distribution of the iron ore slime (sample 1).

The typical iron ore slime is about $95 \%$ passing in $37 \mu \mathrm{m}, 45 \%$ passing $10 \mu \mathrm{m}$, and $17 \%$ passing $3.2 \mu \mathrm{m}$. By combining the sieving analysis with the XRF results, it was possible to estimate the distribution of $\mathrm{Fe}, \mathrm{Si}$, and $\mathrm{Al}$ in the different size fractions, as shown in Figure 2. It was possible to observe that the majority of the iron $(87 \%)$ is present in the fine particle size fractions $(-20 \mu \mathrm{m})$, which are susceptible to report to the tailing by entrainment when performing reverse cationic flotation. At the same way, almost $91 \%$ of the $\mathrm{Al}$ (mainly kaolinite) is distributed in the size fraction below $20 \mu \mathrm{m}$, with low floatability behavior as reported by $\mathrm{Xu}$ and coworkers [11]. On the contrary, $58 \%$ of $\mathrm{Si}$ is below $20 \mu \mathrm{m}$.

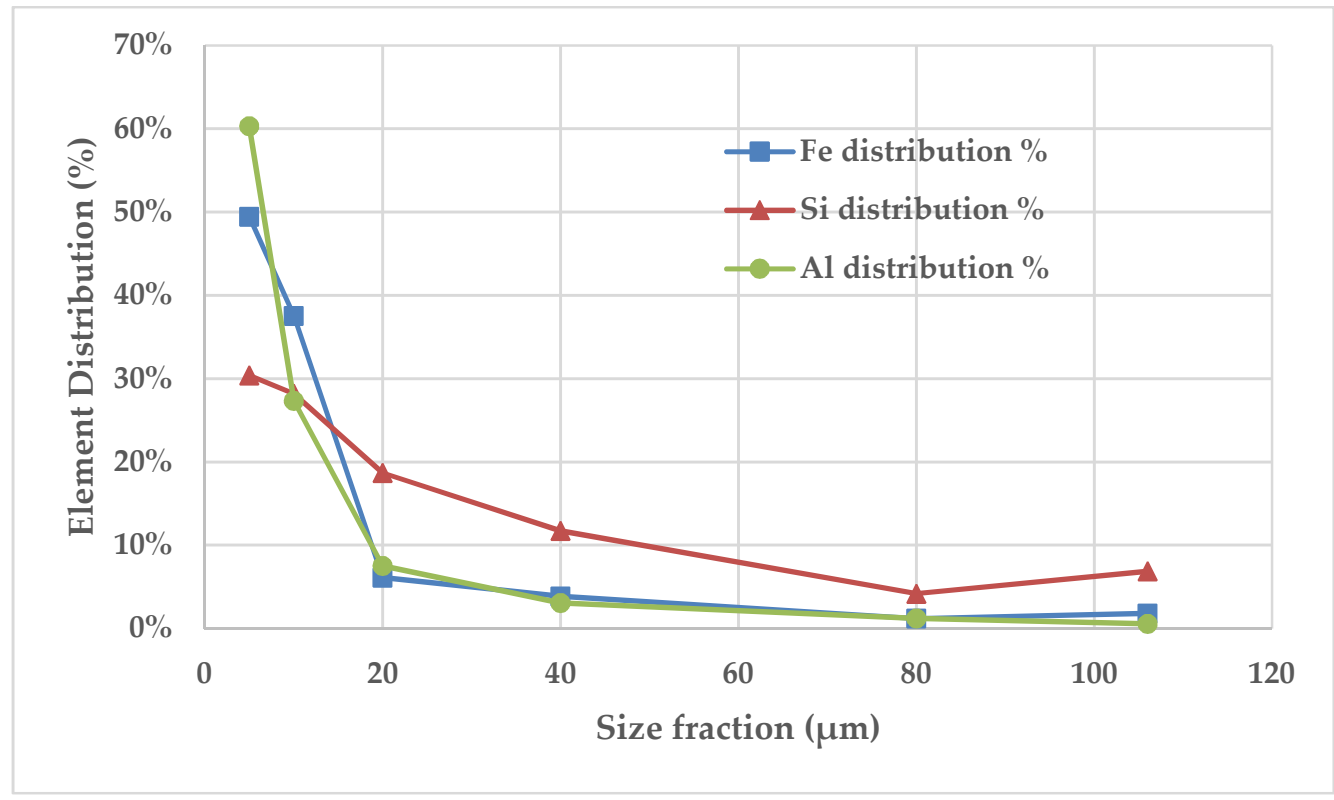

Figure 2. Distribution of $\mathrm{Fe}, \mathrm{Si}$ and $\mathrm{Al}$ according to size fraction of the iron ore slime (sample 1). 
The mineralogical analyses are reported in Figure 3, where hematite is the main iron mineral, and quartz and kaolinite are the main gangue minerals.

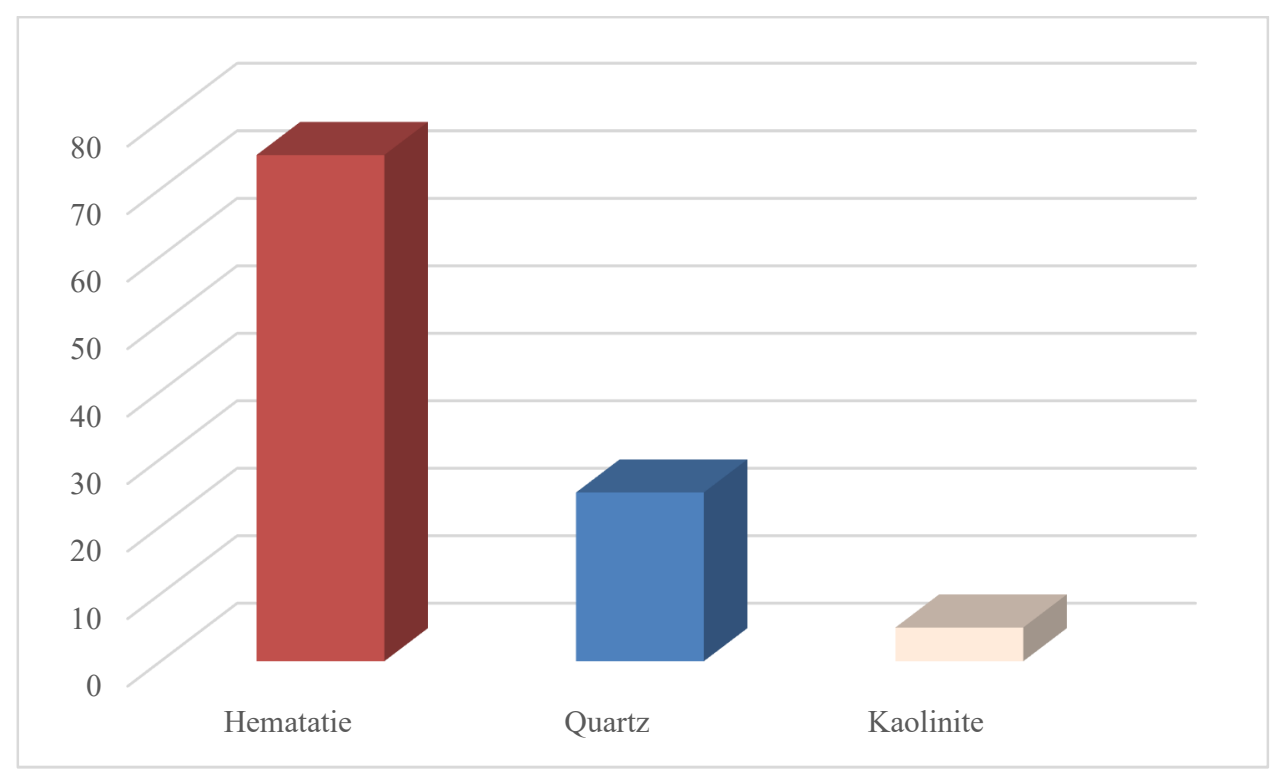

Figure 3. Mineral composition (in \%) of the iron ore slime sample.

Figure 4 illustrates an image of the surface of the hematite, where it is possible to observe the presence of finely disseminated quartz inclusions that appear to be smaller than $2 \mu \mathrm{m}$, which can impact the selectivity of flotation.

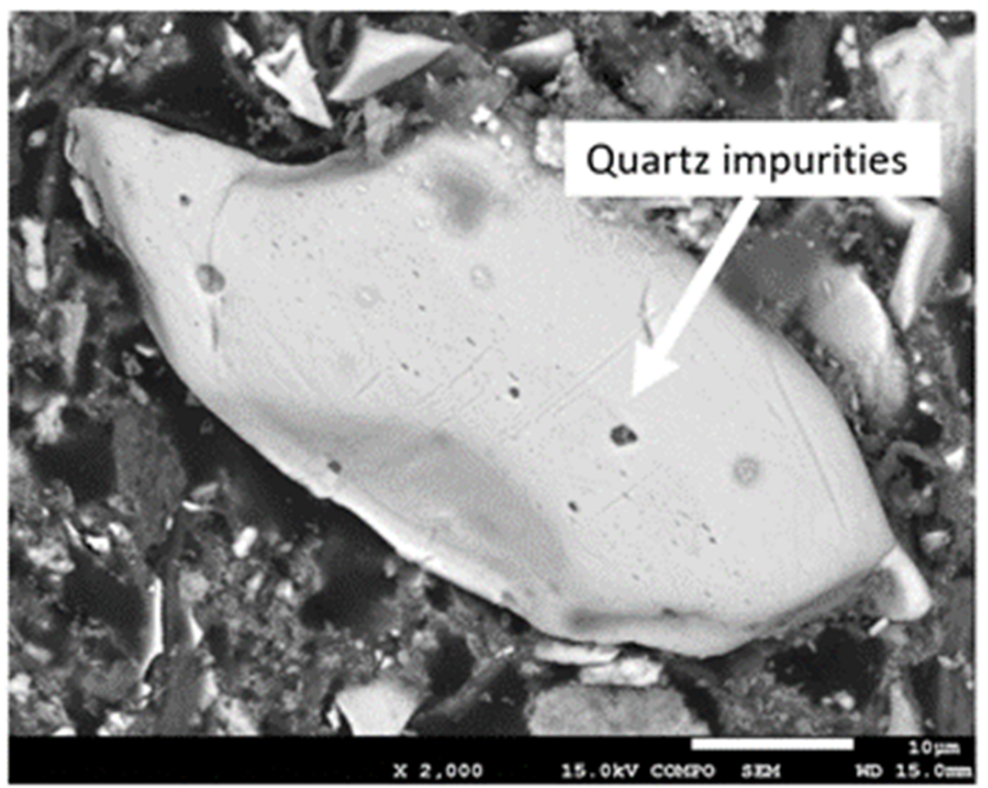

Figure 4. Selected image of the surface of a hematite with finely dispersed quartz (sample 1).

Figure 5 shows the comparative of PSD between the iron ore slime (sample 1) and the products (samples 1A and 1B) obtained after several stages of magnetic concentration and Table 5 show the comparative chemical analyses between them. 


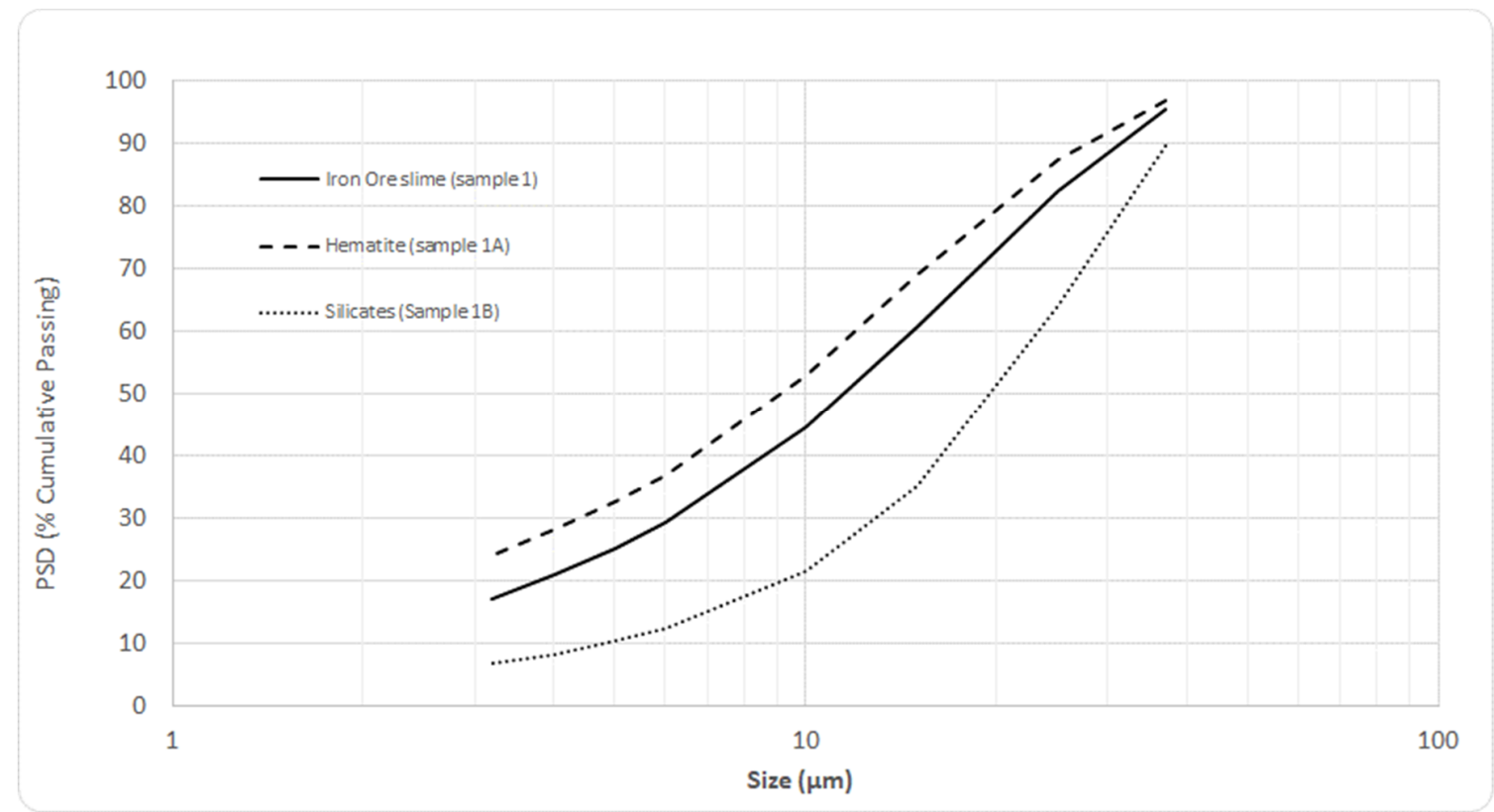

Figure 5. Comparative PSD between the iron ore slime (sample 1), hematite (sample 1A), and the silicates (sample 1B).

Table 5. Comparative chemical analyses between the iron ore slime sample, the hematite and the silicates.

\begin{tabular}{cccccccc}
\hline ID & Mass Recovery & $\mathbf{F e}(\mathbf{\%})$ & $\mathbf{S i O}_{\mathbf{2}} \mathbf{( \% )}$ & $\mathbf{A l}_{\mathbf{2}} \mathbf{O}_{\mathbf{3}} \mathbf{( \% )}$ & $\mathbf{P ~ ( \% )}$ & $\mathbf{M n} \mathbf{( \% )}$ & $\mathbf{L O I}(\mathbf{\%})$ \\
\hline Iron ore slime (Sample 1) & 100 & 45.17 & 28.64 & 3.06 & 0.085 & 0.091 & 3.54 \\
Hematite (sample 1A) & 55 & 66.07 & 2.57 & 0.98 & 0.061 & 0.057 & 1.87 \\
Silicates (Sample 10) & 45 & 17.06 & 60.87 & 6.28 & 0.123 & 0.175 & 8.16 \\
\hline Loss on ignition & & & & & & \\
\hline
\end{tabular}

The hematite of the slime (sample 1A) is much finer than the silicates (1B), in accordance with the size distribution of Figure 2. D50 of hematite is $9 \mu \mathrm{m}$, while d50 of the silicates is $20 \mu \mathrm{m}$.

From the results that are presented in Figure 5, it was deduced that the Iron oxide minerals (hematite) present on the slime sample are much finer than the gangue minerals (silicates). Moreover, after three stages of cleaning with the magnetic separator, the tailing product contains $17.06 \% \mathrm{Fe}$, indicating some association between gangue minerals and Fe minerals.

The finer size distribution of the Fe minerals and their associations with the gangue minerals indicate the challenges and difficulties to concentrate the iron ore slimes and the maximum yielded recovery expected was evaluated as $55 \%$.

Lima and coworkers calculated the degree of entrainment for Fe in different size fractions using an empirical correlation with the water recovery for the rougher, cleaner, and recleaner industrial cells [16]. The results showed the highest entrainment degree for the particles were lower than $20 \mu \mathrm{m}$. This result suggests the iron oxide minerals present on the slimes can be easily lost by entrainment, as almost $80 \%$ are lower than $20 \mu \mathrm{m}$, as shown on the Figure 2 .

Table 6 shows the results of the sedimentation tests with the iron ore slime (sample 1), indicating that the corn starch promotes the concentration of $\mathrm{Al}_{2} \mathrm{O}_{3}$ to the underflow.

When considering that kaolinite is the main mineral of $\mathrm{Al}_{2} \mathrm{O}_{3}$ in the iron ore slime, the increase of the $\mathrm{Al}_{2} \mathrm{O}_{3}$ content to the underflow in the presence of corn starch, can indicate its adsorption on the kaolinite surface. This behavior indicates that the presence of slimes can affect the flotation of quartz by the depression of kaolinite with the corn starch damaging the hematite depression. As the main mechanism of interaction in cationic reverse flotation of quartz is electrostatic, the lack of depression can lead the hematite to be floated by the collector. 
The underflows obtained in the sedimentation tests, with different $\mathrm{Al}_{2} \mathrm{O}_{3}$ contents were submitted to standard bench scale flotation tests. The results of the tests can be seen in the Table 7, where higher percentage of $\mathrm{Al}_{2} \mathrm{O}_{3}$ on the feed (underflow) negatively affected the quality of the flotation concentrate.

Table 6. The effect of corn starch dosage on the recovery of $\mathrm{Al}_{2} \mathrm{O}_{3}$ to the underflow on the sedimentation tests with the iron ore slime (sample 1).

\begin{tabular}{cc}
\hline Corn Starch $(\mathbf{g} / \mathbf{t})$ & Recovery of $\mathbf{A l}_{\mathbf{2}} \mathbf{O}_{\mathbf{3}}$ to the Underflow \\
\hline 0 & 16.5 \\
100 & 43.3 \\
250 & 62.9 \\
500 & 84.7 \\
\hline
\end{tabular}

Table 7. Results of bench scale flotation tests with the products of the sedimentation tests of the iron ore slime (sample 1).

\begin{tabular}{ccc}
\hline $\mathrm{Al}_{\mathbf{2}} \mathbf{O}_{\mathbf{3}}$ Concentrate $\%$ & Fe Concentrate $\%$ & $\mathbf{S i O}_{\mathbf{2}}$ Concentrate $\%$ \\
\hline 1.01 & 65.24 & 1.51 \\
2.21 & 61.91 & 3.34 \\
2.75 & 59.39 & 5.14 \\
3.24 & 56.87 & 6.93 \\
\hline
\end{tabular}

The Al sites of the kaolinite seems to interact with the starch while the Si sites can be free to interact with the collector. This behavior can reduce the floatability of quartz particles, as shown in the results of Table 7 .

Figure 6 shows the combined effect of the distribution of $\mathrm{SiO}_{2}$ in the $+74 \mu \mathrm{m}$ fraction and the presence of slimes on the flotation response, regarding the \% of $\mathrm{SiO}_{2}$ in the concentrate. These tests were realized with samples $2 \mathrm{~A}, 2 \mathrm{~B}$, and $2 \mathrm{C}$ (desliming feeds).

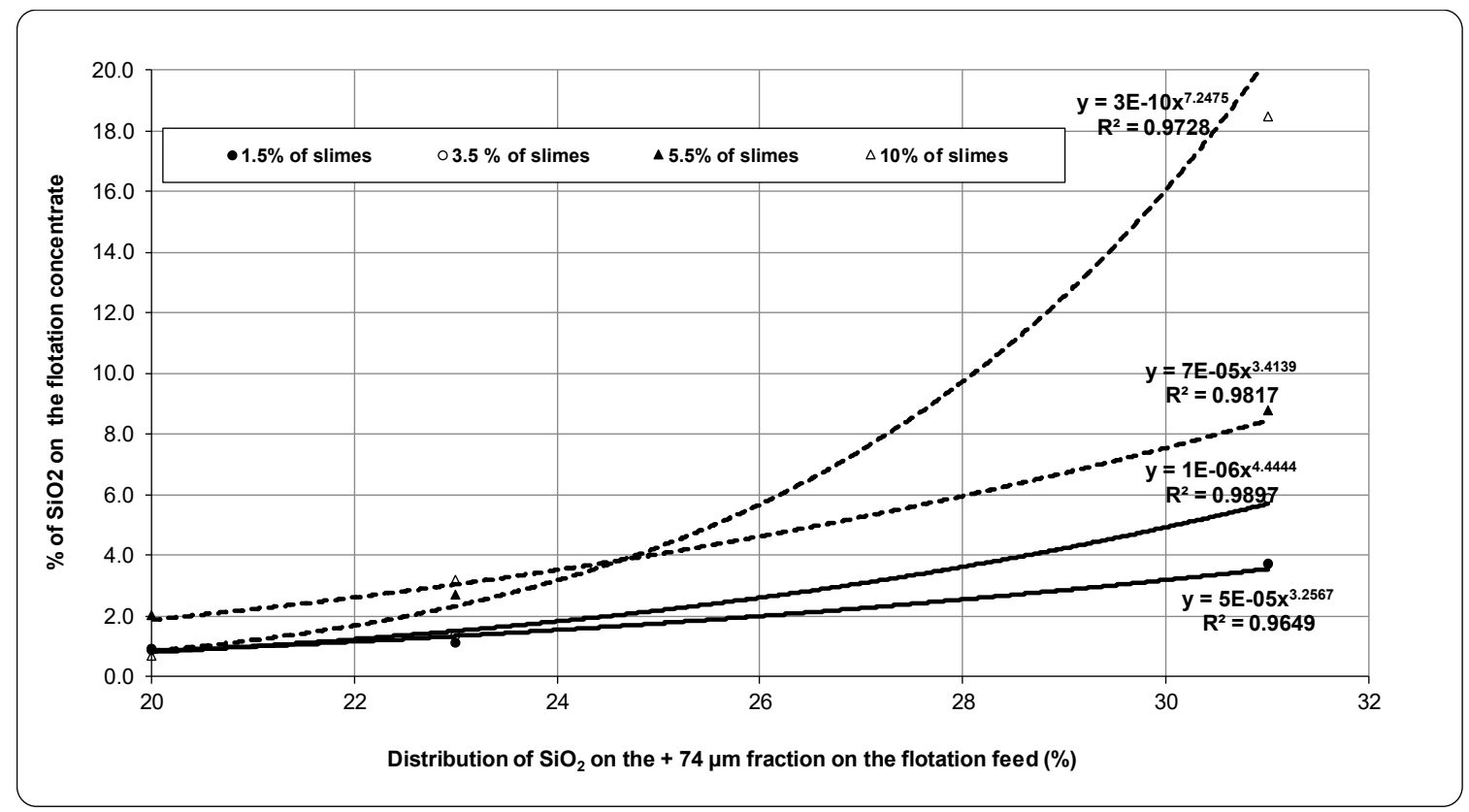

Figure 6. Combined effect of the $\mathrm{SiO}_{2}$ distribution in the $+74 \mu \mathrm{m}$ fraction and the presence of slimes on the flotation response.

The flotation response is drastically impacted with the combination of higher $\mathrm{SiO}_{2}$ distribution in the $+74 \mu \mathrm{m}$ fraction, even for small quantities of slimes, as indicated on the Figure 6 . An increase 
from $1.0 \%$ to $3.0 \%$ of slimes can lead to a drop of almost $10 \%$ in the iron grade in the concentrate. The presence of slimes can adsorb part of the available collector, resulting in insufficient hydrophobicity of the coarse quartz, causing a dropback phenomenon. This behavior is in accordance with the studies conducted by Fugen and cowerkers, where the presence of ultrafine particles $(-10 \mu \mathrm{m})$ caused the high consumption of reagents, suggesting splint the flotation circuit [17]. Another hypothesis is slime coating of small kaolinite particles on the coarse quartz surface inhibiting the collector adsorption or/and the interaction between quartz particles and bubbles. The mechanism of coatings can be controlled by the electrostatic interactions with the kaolinite particles because of the face-edge structure kaolinite [9]. While the negatively charged hematite particles adsorption on the coarse quartz is difficult to occur. Additionally, the coating may be enhanced by the bridging effect of the Ca2+ and other metallic cations [18].

The original size distributions of samples 4 and 5 (pure hematite and pure quartz) are shown in Figure 7. The flotation tests were realized with the mixtures: $80 \%+74 \mu \mathrm{m}$ quartz $/ 20 \%+20 \mu \mathrm{m}$ hematite and $80 \%+74 \mu \mathrm{m}$ quartz $/ 20 \%-20 \mu \mathrm{m}$ hematite.

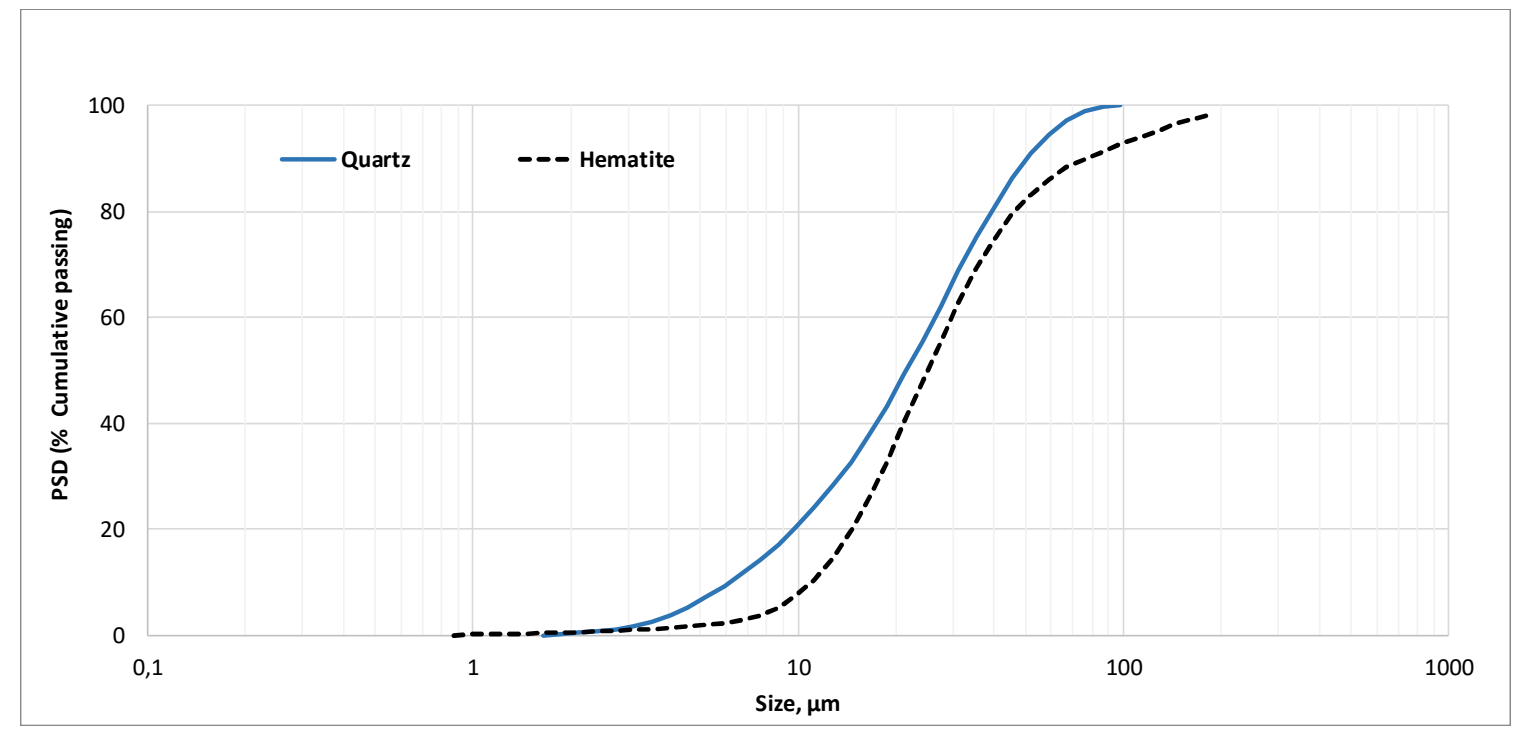

Figure 7. PSD of the pure samples of hematite and quartz (samples 4 and 5).

The harmful effect of slimes on the reverse flotation of quartz can also be observed on the results of Figure 8 , where adding $20 \%$ of the $-20 \mu \mathrm{m}$ hematite reduced the floatability of the coarse quartz particles $(+74 \mu \mathrm{m})$ from $98 \%$ to $62 \%$. On the other hand, the same amount of $+20 \mu \mathrm{m}$ hematite particles did not affect the floatability of these quartz particles. According to the results of Figure 4, 87\% of the hematite in the slime is below $20 \mu \mathrm{m}$, which enhances its effect on the floatability of quartz. These ultrafine particles of hematite can adsorb a large amount of the collector, causing less hydrophobicity of the quartz particles. The other hypothesis to explain the harmful effect of the fine hematite $(-20 \mu \mathrm{m})$ on the floatability of the coarse quartz is the slime coating, as in the study of Bandini and coworkers [14]. At $\mathrm{pH} 10.5$, both particles are negatively charged, however there is still an energy barrier to overcome for slime detachment. When considering that the 2 hematite fractions showed almost the same recovery to the froth, but only the finer $(-20 \mu \mathrm{m})$ decreased the recovery of quartz to the froth, slime coating seems to be the responsible for this harmful effect. 


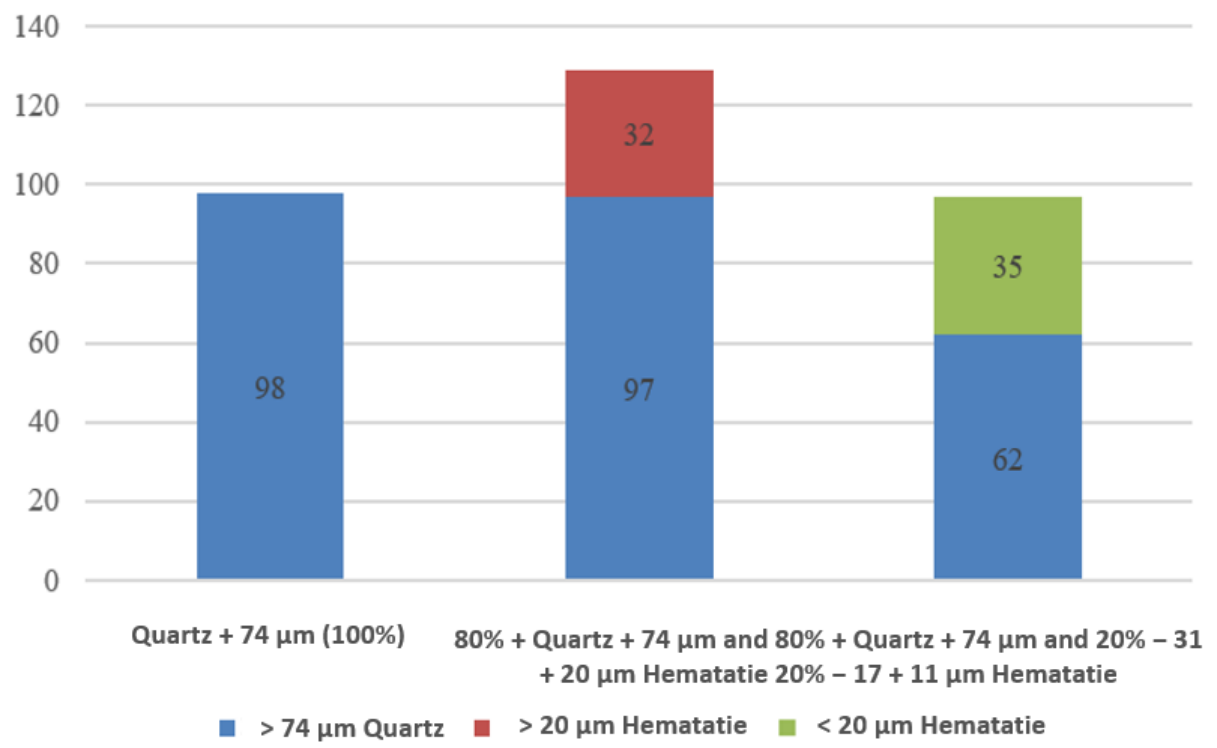

Figure 8. Effect of $+20 \mu \mathrm{m}$ and $-20 \mu \mathrm{m}$ hematite on the floatability of $+74 \mu \mathrm{m}$ quartz $(100 \mathrm{~g} / \mathrm{t}$ of etheramine 7100 by Clariant, $500 \mathrm{~g} / \mathrm{t}$ corn starch, and $\mathrm{pH} 10.5)$.

\section{Conclusions}

Typical slimes from the Iron Ore Quadrangle in Brazil present composition around 70\% of hematite, $25 \%$ of quartz, and $5 \%$ of kaolinite as the main silicate minerals. More than $80 \%$ of the hematite and the kaolinite are below $20 \mu \mathrm{m}$. Some silicates appear as disseminated particles smaller than $2 \mu \mathrm{m}$. The addition of corn starch during sedimentation tests with desliming feed increased the kaolinite depression, which negatively affected the reverse flotation of quartz, possibly by the interactions sites Si-amine-quartz-sites Al-depressor. Moreover, the depressor adsorbs on this silicate minerals surfaces and enhances the harmful effect to the flotation response. The lower floatability of coarse quartz particles $(+74 \mu \mathrm{m})$ combined with the presence of slimes, even in small quantities, drastically impacted the flotation response, which was also observed when hematite particles below $20 \mu \mathrm{m}$, in concentration similar to the desliming feed, reduced the floatability of coarse $+74 \mu \mathrm{m}$ sized particles of quartz from $97 \%$ to $62 \%$. The development of new collectors without the use of traditional depressor might be an opportunity to recover the Fe minerals in the slimes. The effect of kaolinite surface sites and its implication to reagent adsorption is mandatorily for a better understanding of the slime effects on cationic reverse flotation of quartz.

Author Contributions: Data curation, N.P.L., T.S. and L.F.; Investigation, N.P.L. and K.S.; Methodology, N.P.L., K.S. and T.S.; Validation, L.F.; Writing—original draft, N.P.L.; Writing—review \& editing, L.P. All authors have read and agreed to the published version of the manuscript.

Funding: This research received no external funding.

Conflicts of Interest: The authors declare no conflict of interest.

\section{References}

1. Filippov, L.O.; Severov, V.; Filippova, I.V. An overview of the beneficiation of iron ores via reverse cationic flotation. Int. J. Miner. Process. 2014, 127, 62-69. [CrossRef]

2. Lima, N.P.; Valadão, G.E.; Peres, A.E.C. Effect of amine and starch dosages on the reverse cationic flotation of an iron ore. Miner. Eng. 2013, 45, 180-184. [CrossRef]

3. Sahoo, H.; Rath, S.S.; Rao, D.S.; Mishra, B.K.; Das, D. Role of silica and alumina content in the flotation of iron ores. Int. J. Miner. Process. 2016, 148, 83-91. [CrossRef]

4. $\mathrm{Ma}, \mathrm{M}$. Flotation mechanism of kaolinite under reverse cationic flotation conditions. In Advances in Environmental Research; Nova Science: New York, NY, USA, 2011; Volume 12, pp. 197-206. 
5. Clemmer, J.B. Flotation of iron ore. In Proceedings of the 8th Annual Mining Symposium, Duluth, MN, USA, 15 January 1947.

6. Lima, N.P.; Peres, A.E.C.; Marques, M.L.S. Effect of Slimes on Iron Ores Flotation. Int. J. Min. Eng. Miner. Process. 2012, 1, 43-46. [CrossRef]

7. Filippov, L.O.; Filippova, I.V.; Severov, V.V. New technology for producing hematite concentrate from wastes generated in the processing of iron quartzites. Metallurgist 2010, 54, 268-272. [CrossRef]

8. Thella, J.S.; Mukherjee, A.K.; Srikakulapu, N.G. Processing of high alumina iron ore slimes using classification and flotation. Powder Technol. 2012, 217, 418-426. [CrossRef]

9. Ma, X.; Bruckard, W.J. The effect of $\mathrm{pH}$ and ionic strength on starch-kaolinite interactions. Int. J. Miner. Process. 2010, 94, 111-114. [CrossRef]

10. Weissenborn, P.K.; Warren, L.J.; Dunn, L.G. Optimisation of selective flocculation of ultrafine iron ore. Int. J. Miner. Process. 1994, 42, 191-213. [CrossRef]

11. Xu, L.; Hu, Y.; Dong, F.; Jiang, H.; Wu, H.; Zhen, W.; Liu, R. Effects of particle size and chain length on flotation of quaternary ammonium salts onto kaolinite. Mineral. Petrol. 2015, 109, 309-316. [CrossRef]

12. Dey, S.; Pani, S.; Singh, R.; Paul, G.M. Response of process parameters for processing of iron ore slime using column flotation. Int. J. Miner. Process. 2015, 140, 58-65. [CrossRef]

13. Fornasiero, D.; Filippov, L.O. Innovations in the flotation of fine and coarse particles. J. Phys. Conf. Ser. 2017, 879, 012002. [CrossRef]

14. Bandini, P.; Prestidge, C.A.; Ralston, J. Colloidal iron oxide slime coatings and galena particle flotation. Miner. Eng. 2001, 14, 487-497. [CrossRef]

15. Rulyov, N. Turbulent microflotation: Theory and experiment. Colloids Surf. A Physicochem. Eng. Asp. 2001, 192, 73-91. [CrossRef]

16. Lima, N.P.; de Souza Pinto, T.C.; Tavares, A.C.; Sweet, J. The entrainment effect on the performance of iron ore reverse flotation. Miner. Eng. 2016, 96, 53-58. [CrossRef]

17. Fugen, H.; Sivamohan, R. Behaviour of different particle size fractions in the flotation of calcite from wollastonite and microcline. Miner. Eng. 1990, 3, 257-271. [CrossRef]

18. Filippov, L.O.; Dehaine, Q.; Filippova, I.V. Rare earth (La, Ce, Nd) and rare metals (Sn, Nb, W) as by-product of kaolin production, Cornwall-Part3: Processing of fines using gravity and flotation. Miner. Eng. 2016, 95, 96-106. [CrossRef]

(C) 2020 by the authors. Licensee MDPI, Basel, Switzerland. This article is an open access article distributed under the terms and conditions of the Creative Commons Attribution (CC BY) license (http://creativecommons.org/licenses/by/4.0/). 